\title{
Pentahelix Collaboration Approach in Disaster Management: Case Study on Disaster Risk Reduction Forum-East Java
}

\author{
Windiani \\ Department of Development Studies, Institut Teknologi Sepuluh Nopember, Surabaya, Indonesia \\ e-mail:windianiits@gmail.com
}

\begin{abstract}
This article aims to describe the implementation of the pentahelix collaboration approach on disaster management in East Java. The research problem is how the pentahelix collaboration approach was developed by Disaster Risk Reduction Forum in East Java? This study uses a qualitative method, while data collection uses a focus group discussion and participant observation. The finding research showed that the pentahelix collaboration consists of Government, Academics, Community, Business and Media. They have a commitment to collaboration for reducing disaster risk in East Java region which was categorized as a natural disaster-prone area. Besides that, this is considered strategic to be developed in industrial revolution 4.0 era which requires fast information technology, networking and sustainable-collaboration. An interesting findings research is the application of an inclusive approach by involving the disabled community in Disaster Risk Reduction Forum activity.
\end{abstract}

Keywords-Collaboration, Pentahelix Approach, Disaster Management.

\section{INTRODUCTION}

$\mathrm{T}$ HE study of disaster has developed rapidly in various countries including Indonesia in the last decade. Various perspectives and approaches are developed, including in the field of Anthropology [1], Sociology [2], Geography [3]. In Indonesia, disaster studies in social sciences are developed, among others; Irwan Abdullah (2014); Rudi Pramono, (2014), Windiani (2019), Arsita Devi et al (2017). The results of the study generally emphasize the role of social capital in reducing disaster risk. Although it has been studied extensively, studies analyzing the application of a collaborative-pentahelic approach in disaster risk reduction are still limited, so they are considered important, interesting and open up new opportunities to be carried out. This study aims to describe a collaborative-pentahelix approach in disaster risk reduction and the locus study on the Forum for Disaster Risk Reduction in East Java.

There are several reasons why pentahelix collaborative several important reasons for making mitigation (disaster risk reduction and preparedness as an important component of overall disaster management [4]. First, effective response and preparedness activities can save lives, reduce injuries, limiting damage to property and minimizing all kinds of threats due to disasters; second, mitigation and preparedness help protect community values and reduce undesirable conditions during disasters; third, mitigation and preparedness improve coordination and communication between organizations and assign responsibilities to key actor such as ; community officials, state officials, local officials and hospitals; the four mitigation and preparedness help identify resources (personnel, time, finance, equipment, equipment or facilities) that the community may need for response and recovery and preparedness measures $\mathrm{n}$ identify several important functions that need to be performed during a disaster, such as resource management, evacuation and damage assessment.

In implementing disaster management according to Bivaola [4] strong mitigation and preparedness capabilities are the initial problems. Capabilities can be built through planning and training. There are many phases that must be carried out at the preparedness stage including establishing emergency management, assessing disasters, making emergency plans, developing an early warning system and identifying resources and assistance and making agreements to help each other and educate the community. However, research on disasters shows that apathy and a lack of experience in managing disasters are the two main problems faced at the mitigation and preparedness stages. In addition, the value and importance of preparedness and process is sometimes difficult to quantify. At the same time, communities often make complicated contingency plans and fail to develop written written mitigation and emergency preparedness plans in place, but the plans are never disseminated to the community. Therefore pentahelix collaboration is a strategic approach to be developed in disaster management and especially for stakeholders who are committed and concerned about disaster risk reduction efforts.

\section{METHOD}

The type of research is descriptive with used qualitative method. The data was collected by in-depth interviews, Focus Group Discution and participant observation. Determination of informants using purposive sampling technique in accordance with research objectives. Key informants in this study were commitee of Disaster Risk Reduction Forum in East Java, Head of Disaster Management Agency, Media, Academic, Researcher, and Volunteers from Disaster Communities in East Java.

In testing the validity of the data, the researcher uses triangulation technique, which is checking the validity of the data by using something other than the data for checking purposes or as a comparison to the data. This triangulation is carried out to ensure that the data collected actually represents the phenomenon that is the focus of the research. Triangulation is done through interviews, direct observation and indirect observation. This indirect observation is carried out in the form of observing several behaviors and events, 
December $5^{\text {th }}, 2020$, Online Conference

which are then drawn from the results of these observations a common thread connecting various phenomena of events is drawn. In reducing the bias of understanding the researcher with the understanding of the perpetrator, prevention is necessary in the form of triangulation on other objects regarding the same thing. The aim is to compare the information obtained from various parties, so that there is assurance about the level of confidence of the data. This also prevents the subjectivity of researchers.

\section{RESULT AND DISCUSSION}

\section{A. Pentahelix Collaboration Approach In Disaster Management}

Etymologically "pentahelix" comes from "penta" which means five and "helix" is a braid. The Pentahelix approach is based on five types of stakeholders, namely academic, business, community, government and media. This approach is useful for managing actor-based problematic complexity. The pentahelix concept is a manifestation of the spirit of multiculturalism in disaster management in Indonesia. The composition of the diversity of entities can be managed on the basis of a collaborative governance approach. Collaborative governance is a government arrangement in which public institutions directly involve non-state stakeholders in a deliberative joint decision-making process [6]. This collaboration aims to address problems in society through a series of factors that are very important in the collaborative process. These factors are deliberation, building trust, developing commitment and mutual understanding.

Emerson and Nabatchi [7] reveal the fact that a problem of high complexity cannot be solved by an organization that operates alone. More than that, there is a need for collaborative governance encouragement. Thus, collaborative governance with the pentahelix stakeholder approach will have a long-term, sustainable effect if applied in the disaster management process. In addition, the implications of this strategy will improve the quality of democracy which has been injured as a result of the crisis. The implication is that with this strategy, public spaces that had been buried by the pandemic situation have re-emerged. Deliberative discussions between Pentahelix Stakeholders, namely academics, business, civil society (NonGovernmental Organizations), government, and the media must continue to be carried out in making disaster management policies, especially in anticipation and prevention (mitigation).

The involvement of pentahelix stakeholders in handling the outbreak shows that supervision of the government is getting stronger. The rights of every group of society have been accommodated by the collaborative role of pentahelix so that there are no longer exclusive policies that trigger a crisis of public trust. In addition, public value can be achieved on the basis of deliberative thinking without isolating certain groups. It is in line with what Goodsell [8] states that public value must come from the social collectivity of people who act together in the public sphere accompanied by democratic dialogue on common concerns. Therefore, what is valued and believed to be the best solution is not determined only by the government.
Concrete steps to achieve collaborative governance with the pentahelix stakeholder approach can be taken in several ways. However, it needs to be emphasized that there is still a need for the role of the government, in this case the parliament, to oversee the system so that the system operates in the direction of the people's interests. As a democratic institution that holds the voice of the people, parliament can create a shared vision in pentahelix stakeholders of the importance of collaboration to deal with the outbreak. This can be carried out on an inclusive, deliberative and dialogue basis. As a first step, the involvement of these five actors in making decisions on handling the outbreak has indicated that the parliament has succeeded in carrying out shared problems, which then creates social collectivity among them. With these conditions, they are in the same vision.

A democratic public policy will encourage social trust as a precondition for policy effectiveness. Therefore, parliament must also pay attention to the evaluation and criticism of the five pentahelix actors. Their involvement in policies must be without discrimination, and given equal access so that the power gap can be minimized or even eliminated. This process is what is meant by inclusion, where it is necessary to give trust to the program target group to express their voice in interpreting and evaluating the policies they experience. The government as a decision maker cannot work alone. They have to know the problem from the grass roots. Inclusiveness is able to inspire individuals who do not have the "power" to speak to express their aspirations.

Dialogue becomes a concrete basic step for implementing collaborative governance. The dialogue that is formed must be authentic and not repetitive or rhetorical in nature, and must contain an understanding of the differences and interdependence between stakeholders. In this case, the parliament must be able to facilitate the public space based on the multiculturalism understanding of the characteristics of the pentahelix actor. For example, the media has framing; academics carry theoretical practical values that promote evidence based, civil society communities that fight for rights from the grassroots and business people who know the conditions of market movements. By understanding the typical characteristics of these participants, reciprocity can be built, cooperation, learning between stakeholders and that leads to the emergence of creativity for problem solving or in other words, collective problem solving occurs. Thus, the parliament must be able to build a share identity and vision by building trust between stakeholders, reducing power gaps, and having sufficient understanding of information among the five stakeholders. Thus, the opinions, aspirations, and needs of each member can be conveyed openly and community participation becomes active. A series of strengthening inclusion and dialogue in disaster management including the COVID-19 pandemic can produce democratic policies.

The complexity of the problem of disasters is not a problem solely of the government. There is a need for a social collectivity capable of forming global synergies. For this reason, collaborative governance with the Penta Helix 
December $5^{\text {th }}, 2020$, Online Conference

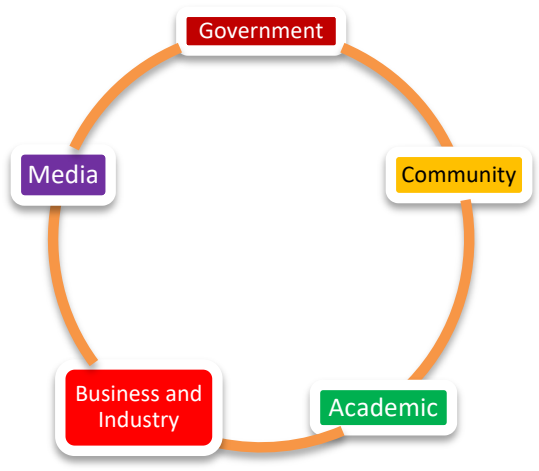

Figure 1. Model of the Pentahelix Collaboration.

Stakeholder approach is a concrete solution to overcoming the pandemic problem. In this case, the parliament as a democratic institution plays an important role in initiating and maintaining the sustainability of this strategy. The democratic values contained in collaborative governance must be maintained and maximized.

The global community must actively participate in helping parliament maintain the existence of democratic values. Parliament is only a facilitator. The real holder of the performance of democracy is each individual. With the spirit of global collaboration and integration, it is not impossible if the pandemic will be resolved immediately considering the creation of collective problem solving.

In implementation, the pentahelix collaboration approach consists of various actors involved. They can come from the government or society, identified as coming from the bureaucracy, the legislature, the judiciary, pressure groups, and community organizations [9]. The actors involved and their roles from the results of this study can be explained as follows. Pentahelix collaboration is a collaborative activity between institutions, between the fields of Academic, Business, Community, Government and Media, otherwise known as ABCGM, which is known to accelerate the development of potential in various developing areas.

The pentahelix element was originally a Triple Helix with elements of Academics, Business Sector, Government, which was then added with one element, Civil Society (or Communities in this study), to become a Quadruple Helix, to accommodate people's perspectives, in this case "society based on media and culture"which has also become an integral part of innovation in the era of the Industrial Revolution 4.0 as it istoday. Model of Pentahelix Collaboration Approach can be seen in Figure 1.

Furthermore, the Communities element opens opportunities for interdisciplinary configuration and networking, and frees the concept of "innovation" from just economic considerations and goals, but also involves creativity as part of the process of producing knowledge and innovation [10]. This is because art-based research and innovation makes it possible to re-think or remodel the models of economic and market development that are being created.

The Quadruple Helix is then added with one more element, namely Media, because in the context of the development of the creative economy in Indonesia, Media (both conventional and social media) plays a significant role, although it remains an independent element or is indirectly influenced by other elements. in carrying out its part or function [11].

In its implementation, several fields in disaster risk reduction have their respective roles and tasks that are synergized with one another. First, Academics on the Pentahelix model can act as innovators, conceptors and research and development. Such as identifying the potential and certification of products and human resource skills that support the development of strategies in disaster risk reduction. Academics in this case are a source of knowledge with the latest concepts, theories and research findings and can carry out community service as an effort to reduce disaster risk.

Second, businness/the private sector in the pentahelix model acts as an enabler. The private sector is an entity that carries out business processes in creating added value and maintaining sustainable growth. The private sector can act as an enabler that provides technology and capital infrastructure. With the change to the digital era, it is hoped that it can help financially in disaster risk reduction, for example in the form of capital support and Corporate Social Responsibility (CSR) which is allocated for people living in disaster-prone areas.

Third, the Community in the pentahelix model acts as an accelerator. In this case, communities are people who have the same and relevant interests in disaster risk reduction. Acting as an intermediary or a liaison between stakeholders to assist the community in the whole process and facilitate the adoption of local values and wisdom in disaster risk reduction. In addition, the community also has a role as an agent of change in efforts to reduce disaster risk, especially in areas that have the potential for disasters.

Fourth, the Government must act as a regulator and facilitator as well as act as a controller that has regulations and responsibilities in developing disaster risk reduction efforts. In this case it involves all types of activities from planning, implementation, monitoring, control, promotion, financial allocation, licensing, programs, legislation, development and knowledge, public innovation policies, support for innovation networks and public-private partnerships.

The government also has a role in coordinating stakeholders who contribute to disaster risk reduction efforts. Fifth, the media must be able to act as an expender. The media plays a role in publishing, promoting inspirational news related to disaster risk reduction activities, providing awareness and education processes to the public about disaster risk reduction efforts in various regions in East JavaIndonesia.

\section{B. How The Disaster Risk Reduction Forum Develop a Collaborative-Pentahelix Approach?}

The Forum of Disaster Risk Reduction (FDRR)-East Java is an organization consisting of various elements, among them, the business community, academics, community organizations, professional organizations, donor agencies, mass media, and disaster management volunteers. FDRREast Java is an organizational forum for actors involved in 


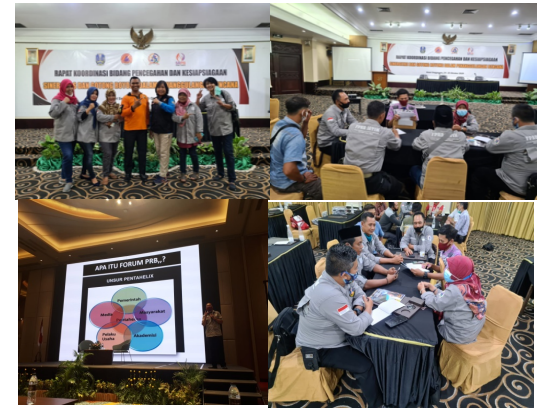

Figure 2. Practice of a Collaborative-Pentahelix approach: FGD and coordination of FDRR-East Java committeein Singgasana Hotel, November $20^{\text {th }}-21^{\text {st }} 2020$. (Source: Researcher documentation, 2020).

disaster management and has a joint commitment in developing a synergistic strategy for disaster risk reduction in the East Java region. These strategies and approaches can work optimally if they are carried out with the synergy of multi-stakeholder collaboratively and continuously.

The Forum of Disaster Risk Reduction Forum (FDRR)East Java was formed since 30 September 2013, with a vision of "Building a Disaster Risk Reduction Movement with the people of East Java". To realize this vision, FDRR-East Java describes the organization's mission, namely "To increase the capacity of members, as a means of communication and coordination between DRR actors and to build the DRR movement in East Java". In a coordination meeting held November $20^{\text {th }}-21^{\text {st }}, 2020$ as seen in Figure 2, the administrators of the Forum of Disaster Risk Reduction -East Java agreed that the FDRR is (1) a manifestation of community participation in disaster management in their regions. (2) The FDRR consists of representatives of business institutions, academics, community organizations, nongovernment organizations, mass media, donors, professional / expertise organizations, legislative, judiciary and regional apparatus organizations, as well as disaster management volunteers. (3) FDRR is a partner of Provincial BPBD and District / City BPBD. FDRR is not a rival to BPBD. (4) FDRR was formed based on Law no. 24 of 2007, PP. 21 of 2008, as well as specifically regulated in Perka BNPB which is in the process of completion. (5) FDRR has a vision: Ensuring Regional Development Based on Disaster Risk Reduction. (6) Ensuring that the policies taken can reduce disaster risk at this time, do not increase the risk of new disasters, and improve the quality of life of the community. (7) Ensuring disaster management institutions can synergize well, between BPBD and Regional Implementing Organizations, between local governments and communities and business institutions. (8) Ensure that disaster management budgets are sufficiently used in disaster management in accordance with disaster risks in the region. (9) Ensure that community empowerment is carried out in the regions in building disaster resilience. (10) Joint targets ensure 7 Resilience Objects: House / Shelter, School / Madrasah, Community Health Center / Hospital, Market, House of Worship, Office, and Vital Facilities. Example of this practice can be seen in Figure 2.

The National Disaster Management Agency (BNPB) through the Deputy for Prevention initiated the establishment and management of the East Java Province Disaster Risk
Reduction Forum (FDRR) together with representatives of the Provincial and District / City Disaster Management Agencies in East Java as well as the Provincial and District FDRRs. / Cities in East Java and held at the Grand Mercure Mirama Hotel, Surabaya, East Java, Monday (26/10) and Tuesday (27/10). The purpose of holding these activities is as a joint effort between BNPB and BPBD throughout East Java Province in initiating the formation of FDRRs in 16 Regencies / Cities, developing FDRRs that have been formed in 22 Regencies/Cities throughout East Java, increasing public awareness of potential threats to La Nina and accelerating the handling of COVID-19 in East Java. Furthermore, BNPB reminded the importance of anticipating potential hydrometeorogical disasters due to the La Nina phenomenon, where Provincial/Regional Governments and Provincial/District/ City Regional Implementing Organizations can hold a Preparedness Coordination Meeting for La Nina starting at the Provincial, Regency/City, District level. /Village/Sub-district, as well as the Community.

With various socialization activities in disaster-prone areas, simulations, preparation of volunteers, to ensuring information is conveyed. Prof. Samsul Maarif (2020) states that delivering disaster affairs is a civil affair, but it remains the responsibility of the government. The FDRR was asked to invite the government to make an operational plan involving 8 clusters, including the TNI/Polri, to be brought to the DPRD in a Public Hearing Meeting. Furthermore, the Head of Sub-Division for Production of Climate and Air Quality Information of the Meteorology, Climatology and Geophysics Agency (BMKG).

Likewise, most of East Java has entered the rainy season with an increase in high rainfall until the end of December 2020. In response to this, BMKG suggested that they have started to optimize integrated water management from upstream to downstream, preparation of river and canal capacity to anticipate water discharge. excess, and optimizing the agricultural sector, especially rainfed land and the energy sector based on hydropower. The East Java Provincial Government had made preparations and anticipation in dealing with La Nina, where there were already 22 districts / cities in East Java that were affected by La Nina. This has been followed up by conducting a preparedness coordination meeting between regional heads at the Regency /City level. FDRR-East Java initiation and management activity is expected to increase awareness and equalize perceptions of the government and activists in the field of disaster management to participate in mainstreaming DRR and provide knowledge about FDRR and La Nina preparedness. To strengthen the Regional Resilience Index from disaster risk, by 2021, all districts / cities in East Java are required to have established Disaster Risk Reduction Forums in their respective regions. The decision was made as a recommendation from the Coordination Meeting for the Establishment and Management of the Disaster Risk Reduction Forum (PRB) which was held by BNPB for two days, Monday-Tuesday (26-27 /10/2020), at the Grand Mercure Hotel, Surabaya.

In this coordination meeting which was attended by the Head of District / City BPBDs throughout East Java, it was determined that all regions must immediately form a DRR 
The $2^{\text {nd }}$ International Conference on Global Development - ICODEV

December $5^{\text {th }}, 2020$, Online Conference

forum as mandated by Law No 24/2007 concerning Disaster Management and Government Regulation number 21/2008 concerning Disaster Management. Head of Prevention and Preparedness of the East Java BPBD (Gatot Soebroto) stated that the FDRR is actually a form of community participation in the field of disaster management.

This forum consists of various elements, among them, the business community, academics, community organizations, professional organizations, donor agencies, mass media, and disaster management volunteers. We must be understood is that the DRR Forum is a BPBD partner, both at the provincial and district/city levels. In the fact, there are 38 regions throughout East Java, 17 regions do not yet have DRR forum. Among them, Surabaya City, Mojokerto City, Malang City, Madiun City, Kab. Bangkalan, Sampang, Pamekasan, Sumenep, Sidoarjo, Probolinggo, Banyuwangi, Bondowoso, Jember, Nganjuk, Ngawi and several other areas. For regions that have not yet established a DRR forum, BPBD must facilitate its formation. The formation of DRR forum in the regions must be based on the pentahelix effect.

Secretary General of East Java FDRR (Sudarmanto, M.MB), stated that he was ready to escort and assist district /city BPBDs in the process of establishing FDRRs in the regions. In order to oversee this process, his party has also established a Person In Charge (PIC) in each region who is tasked with overseeing and coordinating the process of forming the FDRR. "In principle, we just want to help and ensure that the process of establishing FDRR in each region is in accordance with the results of the October 26-27 coordination meeting," said the man who is familiarly called Mbah Darmo. He also hopes that the FPRB that has been formed will not only meet the BNPB's target requirements, but must also take an active role in disaster risk reduction activities in each region. That way, the index of resiliency of each region in East Java will later increase, and the Disaster Risk Index could decrease.

\section{Involvement of Stakeholders in Disaster Risk Reduction in East Java}

In the 2000s the concept of synergy in development developed very fast. The concept of synergy comes from the triple-helix idea adopted from Etzkowitz \& Leydesdorff's theory [12]. The triple helix concept emphasizes the existence of a relationship between universities, industry and government. In 2014, Lindberg developed a new concept called the quadruple helix by adding elements of local society to complement the triple-helix concept that had already developed. The pentahelix concept was adopted by the Government, Higher Education, NGOs. Community, Industry, Media and growing rapidly starting 2018.

The head of the National Disaster Management Agency (BNPB) Doni Monardo said the importance of new concepts in disaster prevention and management by calling it the pentahelix formula, namely an approach that prioritizes the use of local contexts, local wisdom, local resources in accordance with the spirit of mutual cooperation in preventing and overcoming disasters. including the corona virus which is endemic at this time. In this context, the five components (pentahelix) must work together, work together, support and complement each other, namely the government, the business world, the community, academia and the media.
Disasters of any kind must be faced in the context of this pentahelix.

In the spirit of pentahelix, the power to resist various disasters also comes from within the community itself. Local communities have local wisdoms. They have local resources and spirits. This must be empowered. Community awareness must be empowered because in fact they have awareness. The issue of the disaster that occurred in Indonesia, is not only a matter for the Government. Nor is it the responsibility of academics or media interests alone. From a regulatory and policy perspective, that is indeed the government's domain. But at the level of implementation and actualization, it has entered the public domain with its various characteristics.

Basically, the disaster problem is a global public problem and is the collective responsibility of elements in society. Benington in Godsell [8] calls for networked community governance, which is an open collective problem-solving process in which the central authority leads by helping to create a vision of common problems with the aim of obtaining collective solutions. The implication of this thinking is cooperation, synergistic collaboration between the government and various elements of society, academia, industrial business and the media as an answer to overcoming various crises caused by disasters. Credibility and freedom of information flow, deliberative public space, policy choices based on public value preferences, civil society unions, and open interactions between government and society are vital assets to fight the pandemic. All these elements are the basic keys of a democratic system. In this connection, making democracy as a response to the handling of the epidemic can only be built if the general public understands the importance of diversity.

Based on the results of exploration in the field, stakeholders involved in the pentahelix collaboration in the Forum for Disaster Risk Reduction in East Java are the Government (BPBD-Jatim, BPBD Regency-City, Volunteers and Disaster Communities in the East Java region (LPNU, MERC, GERKATIN, JANGKAR KELUD, SUAR Kediri, Community Radio, etc), Academics (UNAIR, ITS, UNIBRAW, UNESA, UNEJ, UINSA, etc), Businnes (Pertamina, Semen Gresik, Cocstruction Consulting), Media (Jawa Post, Bhirawa, East Java News, Community Radio, Radio Modangan, etc) and volunteers from various professional organizations (PGRI), religious (NU, Muhammdiyah, Christian Youth Community, Catholic Youth and Hindu Community) and community; PMR, PMI, Scouts, youth organizations, Gender Community and others [13] [14]. The duties and authorities of disaster management by local governments are administered by the Disaster Management Agency (BPBD) (RI Law No. 24 of 2007 on Disaster Management, Law No. 21 about Management of Disaster Management).

In the disaster management in the East Java region, DRR Forum develops this model based on synergy between stakeholders, known as the collaborative-pentahelix approach. This approach places more emphasis on building collaborative relationships with the five main stakeholders, namely; Government (Central Government- Local Government-Village Government), Academics, Society, Business-Industry and Media who are committed to disaster 
December $5^{\text {th }}, 2020$, Online Conference

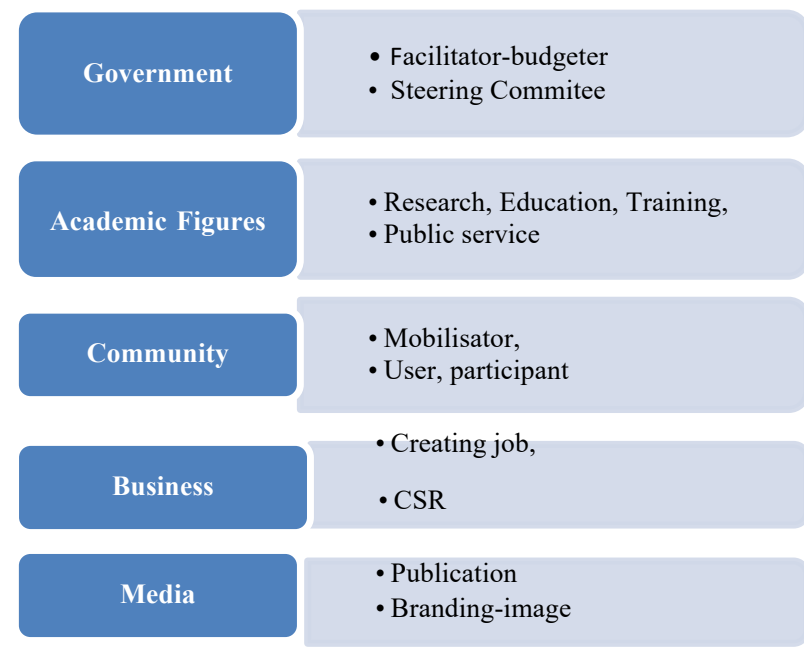

Figure 3. The Role of Pentahelix Stakeholders.

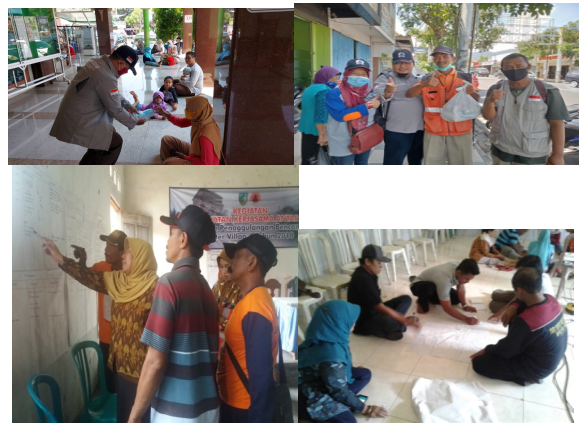

Figure 4. Learning and working with disaster risk reduction community in Kediri and Batu City (Source: Researcher documentation, 2020).

risk reduction. This collaboration pattern involves the main actors (BPBD-Disaster Volunteer Community, Village Alert Team) in disaster management. Through collaborative practices, it is expected to produce productive synergy. The following Figure 3 is a description of the pentahelix stakeholder involvement in the Forum of Disaster Risk Reduction-East Java.

With the context of Indonesia as an archipelagic country, conditioning these various aspirations certainly requires energy and can divide focus. So according to the pentahelix approach, the pattern that can be done is the middle up-down. At this point, both the government and local communities meet in the empowerment space. The government does not patronize the community, on the other hand the people do not demand much of the government. Empowerment space allows the birth of shared awareness about the roles of each party. The government is doing its job and the community also shares its role. Only in this way can any disaster be addressed and its impact prevented.

The Collaborative-Pentahelix approach model as a joint awareness between the government and the community enables this commitment to be carried out, protecting citizens who are still healthy from contracting disease and as much as possible to heal those who have been sick. This communitybased approach is important for reducing the risk of various potential and types of disasters. This condition also provides clarity in the chain of coordination and control in the task force for accelerating disaster management that has been established in the regions as seen in Figure 4.
This strategic approach is expected to be implemented in various fields down to the community level. The pentahelix stakeholders involved must coordinate, cooperate and provide genuine facilitation in the communities. In this context, it is important to avoid being the party who feels the most knowledgeable, truest, most powerful and ignores the strength of the local community, the power of local wisdom and local resources owned by the community. Strong government encouragement and strong community response enable effective prevention and management of disasters that occur in society.

\section{CONCLUSION}

The Collaborative-Pentahelix approach which involves five main stakeholders, namely the Government, Academics, Society, Industrial Business and Media is considered relevant and contextual for the East Java region which is categorized as a natural disaster prone area. The role of stakeholders are; first, Academics on the pentahelix model can act as innovators, conceptors and research and development. Second, The private sector (business) can provide technology and capital infrastructure. Third, the Community in the pentahelix model as an accelerator, mobilisator, and a liaison between stakeholders to assist the community in the whole process and facilitate the adoption of local values and wisdom in disaster risk reduction. With the change to the digital era, it is hoped that it can help financially in disaster risk reduction, and Corporate Social Responsibility (CSR) which is allocated for people living in disaster-prone areas. Fourth, the Government must as a regulator and facilitator as well as act as a controller that has regulations and responsibilities in developing disaster risk reduction efforts. Fifth, the media must be able to act as an expender. The media plays a role in publishing, promoting inspirational news related to disaster risk reduction activities, providing awareness and education processes to the public about disaster risk reduction efforts in various regions in East Java-Indonesia.

In addition, this approach is considered strategic to be developed in accordance with the era of the industrial revolution 4.0 which demands mastery of information technology quickly, the need for networking and collaboration in a sustainable manner. One of the interesting findings in this study is the existence of an inclusive approach, namely by involving the disabled community in Disaster Risk Reduction Forum-East Java.

\section{REFERENCES}

[1] A. O. Smith, S. M. Hoffman, The Angry Earth, 2nd ed. London: Taylor and Francis, 2019

[2] M. B. LaLone, "Neighbors helping neighbors: an examination of the social capital mobilization process for community resilience to environmental disasters," Journal of Applied Social Science, vol. 6 no. 2, pp. 209-237, 2012, doi:10.1177/1936724412458483

[3] I. Kelman. "No change from climate change: vulnerability and small island developing states," The Geographical Journal, vol. 180 no. 2, pp 120-129, 2014, doi: 10.1111/geoj.12019

[4] B. Kusumasari, Manajemen Bencana dan Kapabilitas Pemerintah Lokal, Yogyakarta: Penerbit Gava Media, 2014

[6] C. Ansell, A. Gash, "collaborative governance in theory and practice," Journal of Public Administration Research and Theory," vol. 18 no. 4, pp. 543-571, 2007, doi: 10.1093/jopart/mum032 
The $2^{\text {nd }}$ International Conference on Global Development - ICODEV

December $5^{\text {th }}, 2020$, Online Conference

[7] K. Emerson, T. Nabatchi, "Evaluating the productivity of collaborative governance regimes: a performance matrix," Public Performance \& Management Review, vol. 38 no. 4, pp. 717-747, 2015, doi: 10.1080/15309576.2015.1031016

[8] C. T. Goodsell, "Publicness," Administration \& Society, vol. 49 no. 4 , pp. 471-490, 2017, doi: 10.1177/0095399716656224

[9] J. E. Anderson, Public policymaking: An introduction 1st ed. Boston: Houghton Mifflin Company, 2003

[10] H. A. Muhyi, A. Chan, I. Sukoco, T. Herawaty, "The penta helix collaboration model in developing centers of flagship industry in bandung city," Review of Integrative Business and Economics Research, vol. 6 no. 1, pp. 412-417, 2017, url: https:/www.sibresearch.org/uploads/3/4/0/9/34097180/riber_th16131_412-417.pdf

[11] N. S. Yunas, "Implementasi konsep pentahelix dalam pengembangan potensi desa melalui model lumbung ekonomi desa di provinsi jawa timur," Matra Pembaruan : Jurnal Inovasi Kebijakan, vol. 3, no. 1, pp. 37-46, 2019, doi: 10.21787/mp.3.1.2019.37-46
[12] Z. F. Mamedov, K. Bayramova, "University Development Strategies Commercialization And Responses to New Challenges," $60^{\text {th }}$ International Scientific Conference on Economic and Social Development (ESD), Moscow, Russia, Oct. 2020, pp. 101-108 Accessed on Dec. 15, 2020. [Online]. Available: Economic and Social Development

URL:

https://www.bib.irb.hr/1095944/download/1095944.Book_of_Proceed ings_esdMoscow2020_Online.pdf\#page $=110$

[13] W. Windiani, "Peran institusi lokal dalam pembentukan habitus siaga dan pengembangan mitigasi bencana di kawasan gunung kelud kabupaten kediri," Jurnal Sosial Humaniora, vol. 12, no. 1, pp. 51-65, 2019, doi: 10.12962/j24433527.v12i1.5348

[14] W. Windiani, A. Fahmi, and Z. Muhibbin, "Social Capital in Community Development at Prone Disaster Area: Lesson Learn at Sempu Village-Ngancar Kediri," in The $1^{\text {st }}$ International Conference on Global Development (ICODEV), ITS Surabaya, Dec. 2019, pp. 3137 Accessed on: Dec. 15, 2020. [Online]. Available: IPTEK Journal of Proceeding Series doi: 10.12962/j23546026.y2019i6.6323 